\title{
STRATEGI DAN ARAH PEMBANGUNAN KUALITAS MANUSIA
}

\author{
Novliza Eka Patrisia ${ }^{1}$, Faizal Anwar ${ }^{2}$ \\ Universitas Muhammadiyah Bengkulu ${ }^{1,2}$ \\ novlizaekap@umb.ac.id ${ }^{1}$
}

\begin{abstract}
ABSTRAK
Tujuan penelitian ini adalah untuk menjelaskan strategi dan arah pembangunan kualitas manusia dari perspektif administrasi publik. Metode yang digunakan adalah metode deskriptif, yaitu menggambarkan strategi pembangunan kualitas manusia dari berbagai literatur yang terkait dengan pembangunan sumberdaya manusia (SDM). Hasil kajian literatur menunjukkan bahwa pembangunan kualitas manusia birokrasi merupakan suatu keharusan untuk dapat memberikan pelayanan publik yang memuaskan. Simpulan, Strategi dan arah yang perlu dilakukan oleh pengelola SDM adalah dengan meningkatkan kualitas fisik dan psikis.
\end{abstract}

Kata Kunci: Strategi Pembangunan, Sumberdaya Manusia

\section{ABSTRACT}

The purpose of this study is to explain the strategy and direction of human quality development from the perspective of public administration. The method used is descriptive method, which is describing human quality development strategies from various literatures related to human resource development $(H R)$. The results of the literature review show that the development of quality human bureaucracy is a necessity to be able to provide satisfying public services. Conclusions, Strategies and directions that need to be done by the HR manager is to improve physical and psychological quality.

Keywords: Development Strategy, Human Resources

\section{PENDAHULUAN}

Dari praktisi dan teoritisi sering didengar bahwa administrasi publik di negara berkembang memiliki berbagai kelemahan birokrasi tradisional, misalnya inefiensi, produktivitas rendah, kurang mampu melaksanakan tugas pembangunan, korup, dan sebagainya. Karena itu para ahli seperti Abdullah (1985), Bryant \& White (1987), Brett (1988), Evers (1988), Effendi (1990), Tjokrowinoto (2004), Wibawa (2005), dan Dwiyanto (2006) mensinyalir bahwa salah satu hambatan terbesar dalam pembangunan di negara berkembang, termasuk Indonesia, adalah sistem administrasi publik yang belum memiliki sumberdaya manusia yang cukup untuk melaksanakan berbagai kegiatan pembangunan yang semakin nyata.

Peranan pemerintah dalam pembangunan tetap besar meskipun akan berubah bentuknya. Orientasi baru pembangunan memerlukan perubahan fungsi pemerintah dari "pelaku utama" menjadi "fasilitator". Untuk itu diperlukan suatu sistem administrasi publik yang berbeda dengan sistem yang kita anut selama ini. Sistem 
administrasi baru ini memerlukan struktur yang lebih "organis adaptif", simplifikasi prosedur memiliki orientasi produktivitas dan pelayanan publik, serta lingkungan politik-birokratik yang mampu memberikan pengawasan yang efektif (Brett, 1988; Effendi,1990).

\section{METODE PENELITIAN}

Penelitian ini menggunakan pendekatan kualitatif dengan menggunakan grand teori dari Gregory G. Dess dan Alex Miller. Penentuan informan dalam penelitian ini menggunakan metode snowball sampling merupakan salah satu bentuk judgment sampling, cara pengambilan sampel dengan teknik ini dilakukan secara berantai, teknik penentuan sampel yang mula-mula jumlahnya kecil, kemudian membesar. Dalam penentuan sampel, pertama-tama dipilih satu atau dua orang, tapi dengan dua orang pertama ini data dirasa belum lengkap, maka peneliti mencari orang lain yang dipandang lebih tahu dan dapat melengkapi data dari orang yang sebelumnya. Begitu seterusnya, sehingga jumlah sampel semakin banyak. Pada tingkat operasionalnya melalui teknik sampling ini, responden yang relevan di interview, diminta untuk menyebutkan responden yang lainnya.

Peneliti menggunakan model linear snowball modle. Model snowball linear memungkinkan peneliti bergerak linier untuk menemukan informaan baru, dari satu informan ke informan lain dan membentuk bola salju yang besar secara linier. Untuk mendapatkan data yang diperlukan dan dibutuhkan, subjek penelitian ini menjadi informan yang akan memberikan berbagai informasi yang diperlukan selama proses penelitian melalui wawancara.

\section{HASIL PENELITIAN}

\section{Pembangunan Kualitas Manusia Dalam Birokrasi}

Kiranya tidak berlebihan kalau dikatakan bahwa pemerintah, khususnya sistem administrasinya, pada akhirnya merupakan salah satu faktor penentu utama yang akan mempengaruhi keberhasilan pelaksanakan pembangunan kualitas manusia. Para kritikus birokrasi umumnya masih sepakat bahwa pertahanan birokrasi dalam pembangunan nasional tidak mungkin dapat digantikan sepenuhnya oleh lembaga swasta. Namun di beberapa negara berkembang, termasuk Indonesia, sistem administrasi pembangunan menghadapi banyak hambatan yang sangat mempengaruhi kemampuan sistem tersebut dalam melaksanakan pembangunan kualitas manusia secara baik dan dengan amat memperhatikan martabat manusia.

Peran birokrasi pemerintah yang kuat dan dominan dalam pengelolaan program pembangunan selama ini telah menimbulkan "mental penguasa atau mental priyayi” yang amat kuat dikalangan pejabat birokrasi, dan ini menjadi penghambat yang cukup besar dalam upaya menciptakan aparatur pemerintah yang terbuka, profesional, dan mampu menggalang partisipasi masyarakat dalam pembangunan. Dalam birokrasi seperti itu, prestasi seorang pejabat bawahan akan diukur dari kemampuannya mencapai target yang telah ditentukan atasan serta "kepuasan" 
atasan terhadap prestasi bawahan tadi. Karena itu sifat yang paling menonjol adalah semangat untuk menjaga "keseimbangan" dan "keselarasan" yang berimplikasi pada minimnya perhatian terhadap perubahan dan kemajuan --- yang identik dengan pembangunan. Dengan kata lain, tumbuhlah dengan subur etos kerja status quo yang mendorong para pejaba lebih mempertahankan "keharmonisan" dalam segala hal.

\section{Strategi Meningkatkan Kualitas Manusia Birokrasi}

Kemampuan administrasi pemerintah untuk melaksanakan pembangunan manusia tidak mungkin dapat ditingkatkan tanpa peningkatan kualitas manusia dalam birokrasi pemerintah itu sendiri. Kualitas yang diperlukan oleh petugas birokrasi pemerintah itu, antara lain, mencakup ketaatan pada prinsip-prinsip moral dan agama yang tinggi, rasa kesetiakawanan sosial dalam hubungan sebagai pejabat dan masyarakat, rasionalitas sebagai pejabat yang merupakan individu organisasi atau institusi yang lebih mementingkan tujuan organisasi daripada tujuan individu, serta tingkat kemandirian yang juga tinggi.

Ada beberapa pilihan upaya yang dapat ditempuh oleh para perumus kebijakan, khususnya dalam bidang pembangunan administrasi. Semua upaya ini dilandasi oleh suatu asumsi bahwa dalam pelaksanaan pembangunan kualitas manusia, birokrasi modern adalah satu- satunya wadah implementasi yang tersedia sampai saat ini. Dalam upaya untuk menghasilkan birokrasi yang memiliki efisiensi dan otonomi yang diperlukan untuk meningkatkan kualitas manusia, disadari bahwa hirarki yang terlalu subordinasi yang berlebihan. Karena itu, inti dari upaya untuk meningkatkan kualitas manusia dalam birokrasi meliputi upaya peningkatan produktivitas mereka melalui sistem insentif yang lebih baik, baik financial maupun non-finansial, serta mengubah tata nilai serta tata lingkungan birokrasi melalui:

Pelatihan teknis dan moral. Program pelatihan yang tepat untuk menanamkan budaya produktivitas serta rasionalitas sebagai manusia birokrasi, haruslah mendapat penekanan dalam upaya reformasi administrasi di Indonesia. Program pelatihan manusia birokrasi yang baik dan tepat merupakan pilihan terbaik ketimbang upaya restrukturisasi birokrasi yang sering dilakukan selama ini.

\section{Desentralisasi dan Reintegrasi.}

Pembangunan kualitas manusia dan kualitas masyarakat amat memerlukan desentralisasi kewenangan kepada pemerintah daerah dan kepada masyarakat. Hanya pemerintah daerah yang tahu dengan lebih baik potensi yang dimilikinya serta bagaimana menggunakan potensi tersebut untuk mencapai tujuan yang mereka dambakan. Hambatan-hambatan antarsatuan kerja, di pusat dan daerah, perlu dikurangi secara sistematis dengan mengadakan reintegrasi kebijakan, program, dan kegiatan pembangunan oleh birokrasi pemerintah pusat dan daerah.

\section{Birokratisasi}

Tanpa pengawasan politik yang efektif, birokrasi pembangunan cenderung kurang berprestasi. Karena itu, sejalan dengan upaya menciptakan pengawasan demokratis yang efektif terhadap birokrasi, transformasi ini harus lebih luas dari 
transformasi yang dikenal selama ini, yang bertujuan untuk memperbaiki akuntabilitas dan partisipasi. Yang diperlukan adalah pemberian kekuasaan kepada masyarakat untuk mengembangkan batas-batas organisasi sosial yang bebas dalam suatu masyarakat (civil society).

Menurut World Bank, konsep pembangunan SDM, dalam konteks makro, diartikan sebagai keseluruhan proses aktivitas perluasan spektrum pilihan untuk meningkatkan kemampuan manusia, yang didalamnya tercakup berbagai aktivitas, yaitu pengembangan pendidikan dan pelatihan, kesehatan dan gizi, kesempatan kerja, lingkungan hidup yang sehat, pengembangan di tempat kerja, dan kehidupan politik yang bebas (UNDP, 2001).

Berdasarkan laporan UNDP (2001) diketahui bahwa tingkat pendidikan dan pelatihan diberbagai negara berkorelasi secara positif dengan berbagai indikator lain, seperti penggunaan teknologi informasi dan komunikasi (penggunaan telepon atau internet), persentase wanita di bidang legislatif, dan alokasi anggaran yang responsif pada sektor pendidikan.

Dari beberapa definisi yang telah dikemukakan di atas dapat ditarik kesimpulan bahwa pengembangan manusia birokrasi dilakukan melalui dua cara, yakni pendidikan dan pelatihan. Pendidikan berorientasi kepada peningkatan pemahaman teori, sedangkan pelatihan lebih ditujukan kepada praktik atau teknis. Jadi strategi pengembangannya adalah dengan memberikan birokrasi kerangka kerja dalam meningkatkan kemampuan dan berkembang untuk mengantisipasi dan mendeteksi perubahan lingkungan melalui pendidikan dan pelatihan.

\section{PEMBAHASAN}

\section{Strategi Pembangunan Sumber Daya Birokrasi}

Pada dasarnya profesionalisme birokrasi yang dituntut oleh good governance tidak terbentuk dengan sendirinya. Oleh karena itu Tjokrowinoto (2004) mengatakan bahwa perlu dilakukan beberapa strategi, yaitu (1) Role Modeling. Standar perilaku dan pola perilaku birokrat terbentuk, antara lain, melalui keteladanan. Oleh karena itu spartan elite akan amat menentukan sosok profesionalisme birokrasi; (2) Rekrutmen. Kondisi kerja dan pelatihan. Proses rekrutmen yang objektif, kondisi kerja yang kondusif, dan pelatihan yang menggunakan pendekatan metodik dan dedaktik yang tepat merupakan wacana pembentukan profesionalisme yang efektif; (3) Pendekatan Proses Belajar. Learning process approach sebagaimana yang dikemukakan oleh Korten (2001). Pendekatan ini memberi marjin toleransi yang besar bagi birokrasi untuk berbuat kesalahan (embaring error) dalam proses pembentukan dan penyempurnaan profesionalisme karena kesalahan akan menjadi input untuk perbaikan diri. Melalui kesalahan tadi, manusia birokrasi akan belajar efektif (learning to effective), kemudian akan melangkah menuju belajar efisien (learning to be efficient), dan pada akhirnya akan belajar berkembang (learning to be expand); (4) Dilakukan secara bersama-sama dengan penguatan birokrasi (organizational strengthening) yang memfokuskan diri pada sistem manajemen untuk meningkatkan kinerja pada struktur mikro dan reformasi 
kelembagaan (institutional reform) yang memfokuskan diri pada struktur makro kelembagaan; (5) Memerlukan kontrol sosial dari masyarakat sipil. Meski nampaknya merupakan kontradiksi, di satu sisi profesionalisme birokrasi menuntut kemampuan empowering masyarakat sipil, melalui pembentukan enabling social setting, namun di sisi lain masyarakat sipil perlu melakukan social control terhadap birokrasi. Hal ini menuntut adanya mutual learning process antara birokrasi dan masyarakat.

Lebih lanjut Tjokrowinoto (2004) mengemukakan bahwa salah satu kualitas manusia birokrasi yang dituntut oleh good governance adalah kualitas entrepreneurial yang dapat menjembatani antara state dan market. Karena dalam konteks kecenderungan liberalisasi ekonomi saat ini, kualitas entrepreneurial diperlukan untuk mengintervensi pasar secara selektif berdasar atas pertimbangan yang bersifat ad hoc untuk menjamin berfungsinya pasar secara sehat dan menghindari "the blind force of the market" (Thoha, 2005).

\section{Kompetensi Birokrat yang Diharapkan}

Adapun kompetensi yang dibutuhkan birokrat, menurut Tjokrowinoto (2004), yang berkaitan dengan hal tersebut adalah (1) Sensitif dan responsif terhadap peluang dan tantangan baru yang timbul di dalam pasar. (2) Tidak terpaku pada kegiatan-kegiatan rutin yang terkait dengan fungsi instrumental birokrasi, akan tetapi harus mampu melakukan terobosan (break through) melalui pemikiran yang kreatif dan inovatif. (3) Mempunyai wawasan futuristik dan sistemik. (4) Mempunyai kemampuan untuk mengantisipasi, memperhitungkan, dan meminimalkan risiko. (5) Jeli terhadap potensi sumber- sumber dan peluang baru. (6) Mempunyai kemampuan untuk mengkombinasikan sumberdaya menjadi resource mix yang mempunyai produktivitas tinggi. (7) Mempunyai kemampuan untuk mengoptimalkan sumberdaya yang tersedia dengan mengeser sumber kegiatan yang produktivitasnya rendah menuju kegiatan yang mempunyai produktivitas tinggi.

Birokrat yang mempunyai kualitas entrepreneurial seringkali secara sengaja melakukan destabilizing force dalam rangka menimbulkan creative destruction equilibrium yang satu menunju equilibrium yang lain yang lebih tinggi. Menurut Tjokrowinoto (2004) sikap rasionalitas, imparsialitas, dan impersonal, mendasari kemampuan profesional birokrat. Kompetensi birokrasi lain yang dituntut oleh good governance adalah kemampuan untuk menjembatani antara the state dan civil society. Hal ini tersirat, baik dalam definisi Adil Khan dalam Tjokrowinoto (2004) yang menegaskan bahwa good governance merupakan cara mengatur pemerintahan yang memungkinkan layanan publiknya efisien, sistem pengendaliannya bisa diandalkan, dan administrasinya bertanggung jawab kepada publik.

Selanjutnya menurut J.B. Say yang dikutip oleh Osborne \& Peter (2000) semangat entrepreneurship tidak hanya milik korporasi swasta saja, melainkan dapat pula dimiliki oleh administrasi publik, organisasi non profit, maupun administrasi sektor lainnya. 


\section{SIMPULAN}

Pada dasarnya sumberdaya yang paling bernilai dalam suatu birokrasi adalah sumberdaya aparaturnya. Aparatur melaksanakan dan mengkoordinasi tugastugas, memproses input menjadi output. Birokrasi akan runtuh tanpa manusia birokrasi didalamnya. Jadi wajar kalau manusia birokrasi (birokrat) menjadi perhatian yang serius untuk menciptakan efisiensi dan efektivitas di dalam birokrasi. Untuk menciptakan birokrasi yang efisien dan efektif, perlu pembangunan kualitas manusia birokrasi itu sendiri. Pembangunan sumberdaya manusia bertujuan untuk menjembatani berbagai gap antarvariabel sumberdaya manusia sedemikian rupa sehingga terdapat match and link sepenuhnya antarvariabel tersebut. Pembangunan sumberdaya manusia pada hakikatnya adalah pembangunan manusia sebagai suatu genus makhluk menjadi sumberdaya manusia.

\section{DAFTAR PUSTAKA}

Abdullah, S. (1985). Birokrasi dan Pembangunan Nasional: Studi tentang Peranan Birokrasi Lokal dalam Implementasi Program- Program Pembangunan di Sulawesi Selatan. Ujung Pandang: Universitas Hasanuddin

Brett. E. A. (1988). Adjustment and the State: The Problems of Administrative Reform. IDS Bulletin, IV(4)

Bryant, B., White, W. (1987). Manajemen Pembangunan untuk Negara- Negara Berkembang. Jakarta: LP3ES

Dwiyanto, A. (2006). Reformasi Birokrasi Publik di Indonesia. Yogyakarta: Gadjah Mada University Press

Effendi, S. (1990). Pembangunan Kualitas Manusia: Suatu Perspektif Administrasi Negara. Yogyakarta: Gadjah Mada University Press

Effendi, S. (1989). Pelayanan Publik, Pemerataan, dan Administrasi Negara Baru. Prisma

Evers, H. D. (1988). The Bureaucratization of Southeast Asia, Comparative Studies in Society and History, 29(4) 666-685

Korten, D. C. (2001). Menuju Abad ke-21: Tindakan Sukarela dan Agenda Global. Jakarta (Terjemahan) Yayasan Obor Indonesia

Osborne, D., \& Plastrik, P. (2000). Memangkas Birokrasi: Lima Strategi Menuju Pemerintahan Wirausaha. Jakarta: PPM

Thoha, M. (2005). Birokrasi dan Politik di Indonesia. Jakarta: Raja Grafindo Persada

Tjokrowinoto, M. (2004). Birokrasi dalam Polemik. Pustaka Pelajar bekerjasama dengan UMM Malang

UNDP. (2001). Human Development Report. New York: Oxford University Press

Wibawa, S. (2005). Peluang Penerapan New Public Manajemen Indonesia. Yogyakarta: Gadjah Mada University Press 